\title{
The Nutrition of the Young Ayrshire Calf
}

\section{The Endogenous Nitrogen and Basal Energy Metabolism of the Calf}

\author{
By K. L. BLAX'TER (in Rfceipt of a Sexior Award of the \\ Agricultural Research Council)
}

AND W. A. WOOD

Hannah Dairy Research Institute, Kirkhill, Ayr

(Received 17 fuly 1950)

The concept of an endogenous nitrogen metabolism characterized by the urinary $\mathrm{N}$ excretion on a diet free of $\mathrm{N}$ (Folin, 1905) has been criticized by Schoenheimer \& Rittenberg (1940) on the basis of their demonstration, in experiments on the fate of labelled amino groups in the animal body, of the extraordinary lability of tissue $\mathrm{N}$. Burroughs, Burroughs \& Mitchell (1940) and Mitchell (1948), however, have criticized the conclusion of Schoenheimer that no distinction is possible between the endogenous and exogenous metabolism of protein and have suggested that the endogenous metabolism of Folin represents the summation of those irreversible reactions involving $\mathrm{N}$, exemplified by the reaction creatine $\rightarrow$ creatinine. Whatever interpretation of this $\mathrm{N}$ excretion is made, the determination of the endogenous $\mathrm{N}$ metabolism remains a measure of a basal and inevitable loss of $\mathrm{N}$ from the animal body.

Palmer, Means \& Gamble (1914) showed that the creatinine $N$ excreted daily by men and women was proportional to their basal metabolic rates; in men the ratio, creatinine $\mathrm{N}$ (mg.): basal Calories of heat production, was 1.0 and in women 0.79 . Terroine \& Sorg-Matter (1927) extended these observations and showed that the ratio of total urinary $\mathrm{N}$ plus faecal $\mathrm{N}$ excretion (in $\mathrm{mg}$.) on $\mathrm{N}$-free diets to Calories of basal metabolism ranged from $2 \cdot 2$ to $2 \cdot 6$. This relationship was confirmed by Smuts (1935) who also showed that in mature animals varying in size from mice to pigs the ratio of endogenous urinary $\mathrm{N}$ to basal metabolism was $2 \cdot 0 \mathrm{mg}$. $/ \mathrm{Cal}$. In adult man much lower values have been obtained (Bricker, Mitchell \& Kinsman, 1945; Murlin, Edwards, Hawley \& Clark, I946), some as low as I.4 mg./basal Cal.

In the young animal, the basal metabolism $/ \mathrm{kg}$. body-weight is approximately two to three times that at maturity. In the past it has been usual to express endogenous $\mathrm{N}$ metabolism in $\mathrm{mg} . \mathrm{kg}$. body-weight. It is logical to suppose that the endogenous $\mathrm{N}$ metabolism of the young animal expressed in this way would be considerably higher than that of the mature animal, provided the 'Terroine-Sorg-Matter law' applies during the growth period. Few studies have been made of the effect of age on this relationship. Treichler (1939) has shown that, in the rat, age has a marked effect on the ratio of endogenous $\mathrm{N}$ metabolism to basal metabolism, giving a maximum ratio in early maturity and low values for the young and mature animal.

There are very few estimates of the relationship available for farm animals, for in cattle the only data are those which may be computed from the results of experiments 
conducted for other purposes. Relevant experiments have been summarized by Mitchell (1929), Brody (1930) and Kehar, Mukherjee \& Sen (1943) and these compilations are summarized in Table $\mathbf{I}$. The basal metabolism figures in the table have

Table I. Published data relating to the urinary nitrogen excretion of cattle on nitrogen-low or nitrogen-free diets

\begin{tabular}{|c|c|c|c|c|c|}
\hline Author quoted & $\begin{array}{l}\text { Weight } \\
\text { of animal } \\
(\mathrm{kg} .)\end{array}$ & $\begin{array}{c}\text { Urinary } \\
\mathbf{N} \\
\text { (g./day) }\end{array}$ & $\begin{array}{c}\text { Endogenous } \\
\mathbf{N} \\
(\mathrm{g} . / \mathrm{kg} .)\end{array}$ & $\begin{array}{c}\text { Computed } \\
\text { basal } \\
\text { metabolism } \\
\text { (Cal./kg.) }\end{array}$ & $\begin{array}{c}\text { Ratio } \\
\text { endogenous } \mathrm{N} \\
\text { basal } \\
\text { metabolism } \\
\text { (mg./Cal.) }\end{array}$ \\
\hline $\begin{array}{l}\text { Steenbock, Nelson \& } \\
\text { Hart (1915) }\end{array}$ & 145 & $6 \cdot 48$ & 0.045 & $25 \cdot 7$ & $1 \cdot 75$ \\
\hline $\begin{array}{l}\text { Honcamp, Koudela } \\
\text { \& Muller (1923) }\end{array}$ & 385 & $16 \cdot 32$ & 0.042 & $14 \cdot 9$ & $2 \cdot 81$ \\
\hline $\begin{array}{l}\text { Hart, Humphrey \& } \\
\text { Morrison (1912) }\end{array}$ & 177 & $6 \cdot 33$ & 0.036 & $23 \cdot 4$ & $\mathrm{I} \cdot 54$ \\
\hline Honcamp et al. (1923) & 440 & $16 \cdot 40$ & 0.035 & $13 \cdot 0$ & $2 \cdot 69$ \\
\hline Buschmann (1907) & 443 & $15 \cdot 0$ & 0.034 & $13 \cdot 0$ & $2 \cdot 6 I$ \\
\hline Hart et al. (1912) & 168 & 5.03 & 0.030 & 23.4 & $1 \cdot 28$ \\
\hline Buschmann (1907) & 485 & $14 \cdot 0$ & 0.029 & $12 \cdot 7$ & $2 \cdot 28$ \\
\hline $\begin{array}{l}\text { Hutchinson \& Morris } \\
\left(193^{6}\right)\end{array}$ & $?$ & $12 \cdot 70,20 \cdot 91$ & 0.039 & $13 \cdot 0$ & $2 \cdot 93$ \\
\hline \multirow[t]{2}{*}{ Kehar et al. (1943) } & $\begin{array}{l}255 \\
437\end{array}$ & $\begin{array}{l}5 \cdot 00 \\
8 \cdot 42\end{array}$ & $\begin{array}{l}0.020 \\
0.019\end{array}$ & - & - \\
\hline & \multicolumn{4}{|c|}{ Mean, ignoring Kehar et al. (1943) } & $2 \cdot 24$ \\
\hline
\end{tabular}

been computed from estimates of basal metabolism based on the equations given by Brody (1945). The results of Kehar et al. (1943) have not been used in the computation of the average, since no estimates of basal metabolism are available for Hariana bullocks under Indian conditions. The mean value of $2 \cdot 24 \mathrm{mg}$. N/basal Cal. is in substantial agreement with the Terroine-Sorg-Matter law. It will be noted, however, that the lowest values of the ratio are for the smaller and younger cattle. The studies of Swanson \& Herman (1943) on the endogenous $N$ metabolism of cattle involving sixteen determinations were analysed by us statistically. When taken together with Brody's estimates of basal metabolism the results shown in Table 2 were obtained, suggesting that the

'Table 2. The endogenous nitrogen metabolism of cattle computed from the equations of Swanson EO Herman (1943) and of Brody (1945)

$\begin{array}{ccccc}\begin{array}{c}\text { Body- } \\ \text { weight } \\ \text { (kg.) }\end{array} & \begin{array}{c}\text { Endogenous nitrogen } \\ (\mathrm{g} .)^{*}\end{array} & \begin{array}{c}\text { Basal } / \mathrm{kg} .) \\ \text { metabolism } \\ \text { (Cal.) }\end{array} & \begin{array}{c}\text { Ratio } \\ \text { endogenous N: } \\ \text { basal metabolism } \\ \text { (mg./Cal.) }\end{array} \\ 50 & 3.68 & 0.073 & 1671 & 2 \cdot 20 \\ 100 & 4.92 & 0.049 & 2899 & 1 \cdot 69 \\ 200 & 6.59 & 0.033 & 4532 & 1.45 \\ 400 & 8.81 & 0.022 & 6379 & 1.38\end{array}$

* Computed from equation $E=0.712 m^{0.42}$ (Swanson \& Herman, 1943), where $E=$ endogenous $\mathrm{N} /$ day and $m=$ body-weight in $\mathrm{kg}$.

+ Computed from equation $\frac{Q b}{m}=28 e^{-0.0015 m}+11 \cdot 4$ (Brody, 1945), where $m=$ body-weight in kg. $Q b=$ basal metabolism Cal. 
ratio is highest in the smallest animal. This is probably due to errors of extrapolation of Swanson \& Herman's equation, but in any case there are no experimental data or reliable estimates available on the relationship for the really young bovine.

Experiments were, therefore, carried out in which both the endogenous $\mathrm{N}$ metabolism and the basal metabolism were estimated in calves. The primary object of the experiments was to obtain an estimate of the endogenous $\mathrm{N}$ metabolism of the calf to permit estimation of the protein requirements for maintenance and growth by the Mitchell (1929) factorial procedure as modified by Blaxter \& Mitchell (1948). Subsidiary objects were to study the distribution of urinary $\mathrm{N}$ in specific nitrogen inanition, the faecal $\mathrm{N}$ excretion of the young calf and the digestibility of diets containing dried milk.

\section{Plan of experiment}

\section{EXPERIMENTAL}

The experiment was planned to include four periods as follows: (I) A preliminary period of 14 days when a medium-protein diet was given. (2) A nitrogen-free feeding period of 8 days. (3) A recovery or final period of 6 days on the same diet as used in the preliminary period. (4) A period of starvation of $24-36 \mathrm{hr}$. at the end of which the basal energy metabolism was determined.

\section{Calves and their management}

Details of the three Ayrshire bull calves used are shown in Table 3.

\section{Table 3. Details of experimental calves}

\begin{tabular}{|c|c|c|c|c|}
\hline $\begin{array}{l}\text { Calf } \\
\text { no. }\end{array}$ & $\begin{array}{l}\text { Age at } \\
\text { commence- } \\
\text { ment of } \\
\text { experiment } \\
\text { (days) }\end{array}$ & $\begin{array}{c}\text { Initial } \\
\text { weight } \\
\text { (kg.) }\end{array}$ & Notes & $\begin{array}{c}\text { Diet } \\
(1 . / \text { day })\end{array}$ \\
\hline I & 40 & $34 \cdot 2$ & $\begin{array}{l}\text { A thin, poorly } \\
\text { nourished calf }\end{array}$ & $3 \cdot 6$ \\
\hline 2 & 5 & $27 \cdot 6$ & Normal & 2.8 \\
\hline 3 & 5 & $33 \cdot 2$ & Normal & 3.4 \\
\hline
\end{tabular}

Calf no. I had already been used as an experimental animal and had been given lowcalorie diets before the present experiment; calves nos. 2 and 3 received colostrum and whole cow's milk before the experiment.

The calves were housed in a room in which the air temperature was maintained between 55 and $65^{\circ} \mathrm{F}$. by electric heaters. The night temperature fell on several occasions, however, to $52^{\circ} \mathrm{F}$. and on two occasions the day temperature reached $70^{\circ} \mathrm{F}$. In general over the $24 \mathrm{hr}$. a temperature gradient of $8^{\circ} \mathrm{F}$. occurred.

The calves were confined to metabolism stalls with wire-mesh floors, permitting the quantitative collection of urine. Faeces were collected in light-weight watertight rubber faeces-bags attached by straps of rubber tubing to a single girth band of light canvas. The calf's tail was kept outside the faeces bag by means of a tight-fitting hole at the top of the bag. Each bag was removed daily and was replaced by a clean one. Since it was impossible to remove the whole of the faeces from the bag without washing 
it, the weight of the faeces was obtained by noting the difference between the weight of the empty and full bag. Samples of urine and faeces were taken daily. All analyses were made on samples of pooled urine and pooled faeces, each representing a 2-day period, the only exception being urinary total $\mathrm{N}$, which was determined daily.

The animals were weighed to the nearest $100 \mathrm{~g}$. at 2-day intervals.

Pulse rates were recorded twice daily on each day of the experiment.

\section{Diets}

The experimental diets used are shown in Table 4. Their composition was based on the experience of Wiese, Johnson, Mitchell \& Nevens (1947) and of Aschaffenburg, Bartlett, Kon, Walker, Briggs, Cotchin \& Lovell (1949). No roughage or bedding of

Table 4. Composition of the experimental diets

\section{Constituent}

Dried skim milk powder (g./l.)

Lard (g./1.)

Cod-liver oil (ml./l.)

Glucose (g./1.)

Mineral mixture no. $2^{*}$ (g./1.)

Yeast extract (ml./calf)

Dry matter (g./1.)

Energy value (Cal./l.) (calculated)

$N$ (g./l.) (bo analysis)

\begin{tabular}{|c|c|}
\hline $\begin{array}{l}\text { Normal } \\
\text { diet, } \\
\text { diet no. } 6\end{array}$ & $\begin{array}{c}\text { N-free } \\
\text { diet, } \\
\text { diet no. } 7\end{array}$ \\
\hline $77 \cdot 6$ & Nil \\
\hline $35^{\circ} 9$ & 38.7 \\
\hline $\begin{array}{r}3.3 \\
14.8\end{array}$ & $\begin{array}{r}3.3 \\
95.0\end{array}$ \\
\hline $\begin{array}{l}\mathrm{r} \cdot 3 \dagger \\
\mathrm{Nil}\end{array}$ & $\begin{array}{l}13.0 \\
20\end{array}$ \\
\hline 130 & 147 \\
\hline $\begin{array}{l}740 \\
4.6-4^{\circ} 8 \\
\text { depending on } \\
\text { sample }\end{array}$ & $\begin{array}{l}750 \\
<0.1 \pm\end{array}$ \\
\hline
\end{tabular}

* See Table 5.

$f$ In this mineral mixture magnesium was supplied as the sulphate.

$\ddagger$ Varied slightly from calf to calf, each calf receiving $35.6 \mathrm{mg} . \mathrm{N}$ daily in the yeast extract.

any kind was allowed. The normal diet, diet no. 6 , was made by dissolving the dried skim milk and glucose in water at $40^{\circ}$, raising the temperature of the solution to $70^{\circ}$ and homogenizing both the lard and cod-liver oil into it at high pressure. The minerals were then added and the 'milk' made to volume. Sufficient was made to last for 3 days, and was stored at $0-5^{\circ}$ in an immersion cooler. The $\mathrm{N}$-free diet, diet no. 7 , was made by homogenizing the fat directly into the glucose solution at a temperature of $85^{\circ}$. With this diet emulsifying agents had to be used to give stable emulsions. After considerable trial on a small scale, sodium tauroglycocholate, cholesterol and a proprietary preparation of sodium alkyl sulphates were found to be suitable agents. The same efficiency of homogenization was found when lecithin was used as an emulsifying agent. The quantities used in each 4 gal. ( 181 .) batch were ro g. sodium tauroglycocholate, $5 \mathrm{~g}$. cholesterol and $8 \mathrm{ml}$. of the sodium alkyl-sulphate solution. Failure to homogenize the diet has been shown to cause profuse diarrhoea in the young calf and a loss of hair (Bate, Dwight \& Cannon, 1946). We have noted similar diarrhoea in calves given poorly emulsified diets.

The mineral mixture used is shown in 'Table 5. This was made to resemble the ash constituents of whole cow's milk, with the exception that the magnesium content was 
Table 5. Mineral mixture no. 2 used to supplement the diets of the calves

\begin{tabular}{l}
\multicolumn{1}{c}{ Major } \\
constituents \\
$\mathrm{CaHPO}_{4} \cdot 2 \mathrm{H}_{2} \mathrm{O}$ \\
$\mathrm{K}_{2} \mathrm{HPO}_{4}$ \\
$\mathrm{CaCl}_{2}$ \\
$\mathrm{MgO}^{\mathrm{Na}}$ \\
$\mathrm{Na}_{2} \mathrm{HPO}_{4} \cdot 12 \mathrm{H}_{2} \mathrm{O}$ \\
$\mathrm{NaCl}$ \\
$\mathrm{CaCO}$ \\
Citric acid
\end{tabular}

Quantity
(g.)
200
350
100
40
150
80
100
150

Quantity

(g.)

0.5

0.5

0.5

$0 \cdot 1$

I.O

20.0

0.5

Table 6. Major elements supplied by the mineral mixture compared with those supplied by cow's milk

\begin{tabular}{|c|c|c|c|c|c|c|c|}
\hline Cow's whole milk* & $\begin{array}{l}\text { Calcium } \\
\mathbf{1 2 0}\end{array}$ & $\begin{array}{l}\text { Phosphorus } \\
\text { 100 }\end{array}$ & $\begin{array}{l}\text { Sodium } \\
5^{\circ}\end{array}$ & $\begin{array}{l}\text { Potassium } \\
\text { 150 }\end{array}$ & $\begin{array}{l}\text { Chlorine } \\
\text { y Io }\end{array}$ & $\begin{array}{l}\text { Magnesium } \\
\quad 12\end{array}$ & $\begin{array}{l}\text { Citrate } \\
15^{\circ}\end{array}$ \\
\hline $\begin{array}{l}\text { Mineral mixture no. } 2 \\
\left(\mathrm{mg} . / \mathrm{s} \cdot 3^{8} \mathrm{~g} .\right)\end{array}$ & $122 \cdot 4$ & 110.3 & $50 \cdot 2$ & $156 \cdot 8$ & $111 \cdot 8$ & $24 \cdot 3$ & 148 \\
\hline
\end{tabular}

doubled to prevent hypomagnesaemic tetany, and the essential minor elements were included. A comparison of the minerals supplied with those present in whole milk is given in Table 6. The yeast extract used was prepared according to the method of Macrae, El Sadr \& Sellers (1942).

The diets were given to each calf in the quantities shown in Table 3. On every occasion the diet was warmed to $37^{\circ}$ by immersion in a hot water-bath.

The following analytical methods were used:

Urine: Total N (Kjeldahl, using copper and selenium as catalysts); urea (Van Slyke \& Cullen, I910); ammonia (Van Slyke \& Cullen, I910); creatine and creatinine (Folin, 1914); uric acid (Benedict \& Franke, 1922); allantoin (Larson, 1931-2); glucose (Benedict, 19II).

Faeces: Total N (Kjeldahl); dry matter (direct drying at $100^{\circ}$ ); ash (incineration at $55^{\circ}$ ); fat and soaps (Saxon, 1914). Non-protein $\mathrm{N}$ was determined on trichloroaceticacid or alcohol filtrates of fresh faeces.

Basal metabolism. The oxygen consumption and carbon-dioxide production of each calf were determined after it had fasted for $24 \mathrm{hr}$., using the apparatus and technique described by Blaxter \& Howells (195 I). Collection of expired air for periods of $30 \mathrm{~min}$. was made when the calf was lying quietly.

\section{RESULTS}

Body-weight. Changes in body-weight were not regular from weighing to weighing, although the calves were always weighed at the same time of day and before feeding. Differences in contents of bladder and digestive tract could account for this variation. Table 7 summarizes the changes in body-weight during the three periods.

With the exception of calf no. 3 in the preliminary period, in the periods when the calves were given diet no. 6 they gained in weight. The failure of calf no. 3 to gain was 
largely due to acute diarrhoea and subsequent treatment by reduction of food intake and realimentation over a period of 4 days. In the 6 days following recovery from diarrhoea the gain in weight of this calf was $200 \mathrm{~g}$./day. During the $\mathrm{N}$-free feeding period, weight was lost to a small extent by calves nos. I and 3 , whereas calf no. 2 continued to gain, though at a reduced rate. The normality of the gains in weight of these calves may be judged from the data compiled by Brody (1945). In the ist month after birth Ayrshire calves grow at the rate of about $17 \mathrm{lb}$./month, or $257 \mathrm{~g}$./day; in the 2nd month the growth rate increases to $30 \mathrm{lb}$./month, or $45^{\circ} \mathrm{g}$./day. On this basis the gains of all calves during the period when diet no. 6 was given were subnormal.

\begin{tabular}{lccc}
\multicolumn{4}{c}{ Table 7. Changes in the body-weight of the calves $(\mathrm{g} . /$ day $)$} \\
Period & Calf no. I & Calf no. 2 & Calf no. 3 \\
Preliminary (diet no. 6) & +213 & +219 & -156 \\
N-free (diet no. 7) & -58 & +158 & -33 \\
Final (diet no. 6) & +211 & +237 & +237
\end{tabular}

Pulse rate and general behaviour. There was a slight rise in the pulse rates of the calves during the first few days on which the low- $\mathrm{N}$ diet was given. Increased rates were observed in all calves, but the daily variation was not sufficient to warrant a conclusion that the effect in each individual was significant. A general decline in pulse rate with progress of the experiment from initial values greater than 100 to values of $70-85$ occurred. This appeared to be an age effect, probably related to a decline in metabolism with advancing age of the young animal. The pulse rate of calf no. 3 during the period of diarrhoea when its food intake was reduced dropped to $60-65 / \mathrm{min}$. These data were not included in the statistical analyses.

Throughout the periods in which diet no. 6 was given, all calves behaved normally with the exception of calf no. 3 , as noted above. In the $\mathrm{N}$-free feeding period, however, difficulties arose in persuading the calves to eat the diet. This was not an immediate reaction. All calves consumed the diet without concern for the first 3 days. On the

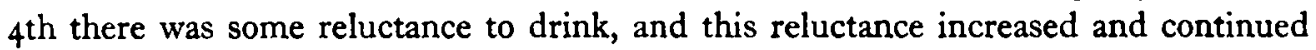
throughout the remainder of the period. Similar disturbances of appetite on feeding low-N diets to sheep have been observed by Miller (1937) and by Ferguson \& Neave (1943).

All calves had diarrhoea at times when given the $\mathrm{N}$-free diet. 'This appeared to be the result of a dietetic disturbance rather than bacterial infection and was probably due to the calves' inability to homogenize their faecal excretion of fat into the fluid phase on this diet. Slight shivering of the calves was noted on several occasions. Its cause is not known, but it was not an indication of increased excitability since the calves were lethargic and dull throughout. Otherwise the calves behaved normally in every respect and, despite the diarrhoea, seemed content. At the end of the experiment the calves were slaughtered. Their rumens were quite undeveloped, though some growth had occurred. It was clear that no active fermentation of the diets had taken place in this organ.

Digestibility of the diets. Table 8 summarizes the data relating to faecal excretion of water and dry matter and the apparent digestibility of the ingested dry matter. 
Although the day-to-day variation in faecal excretion was quite large, it is clear that large increases in the mean faecal excretion occurred when the calves were given the $\mathrm{N}$-free diet. Analysis of variance of the results in Table 8 showed that statistically the increase in dry matter and water excretion was highly significant $(P<0.00 \mathrm{I})$, as was the fall in digestibility of the dry matter of the diet. The number of degrees of freedom for testing was, however, only two.

Table 8. Mean daily excretion of water and dry matter in the faeces and digestibility of the dry matter ingested by the calves

\begin{tabular}{|c|c|c|c|}
\hline $\begin{array}{l}\text { Calf } \\
\text { no. }\end{array}$ & $\begin{array}{c}\text { Preliminary } \\
\text { period, } \\
\text { diet no. } 6\end{array}$ & $\begin{array}{c}\text { N-free period, } \\
\text { diet no. } 7\end{array}$ & $\begin{array}{l}\text { Final period, } \\
\text { diet no. } 6\end{array}$ \\
\hline \multicolumn{4}{|c|}{ Mean daily excretion of dry matter (g.) } \\
\hline $\mathbf{I}$ & $32 \cdot 3$ & $122 \cdot 5$ & $49 \cdot 6$ \\
\hline 2 & $21 \cdot 0$ & 112.4 & $18 \cdot 3$ \\
\hline 3 & $25 \cdot 2$ & $100 \cdot 0$ & $24 \cdot 7$ \\
\hline Mean & $26 \cdot 2$ & $111 \cdot 6$ & $30 \cdot 9$ \\
\hline \multicolumn{4}{|c|}{ Mean daily excretion of water (g.) } \\
\hline $\mathbf{I}$ & $165^{\cdot 6}$ & $989 \cdot 3$ & $216 \cdot 9$ \\
\hline 2 & $\begin{array}{l}93 \cdot 7 \\
64 \cdot 3\end{array}$ & $\begin{array}{r}435^{\circ} 1 \\
1366.2\end{array}$ & $\begin{array}{l}88 \cdot 4 \\
87.5\end{array}$ \\
\hline Mean & $107 \cdot 9$ & $930 \cdot 2$ & 130.9 \\
\hline \multicolumn{4}{|c|}{ Mean daily apparent digestibility of dietary dry matter $(\%)$} \\
\hline I & $93 \cdot 2$ & $77 \cdot 3$ & $89 \cdot 6$ \\
\hline 2 & $94^{\circ} 4$ & $73 \cdot 2$ & $95^{\cdot} \mathrm{r}$ \\
\hline 3 & $94 \cdot 3$ & $80 \cdot 4$ & $94 \cdot 5$ \\
\hline Mean & $94^{\circ} \circ$ & $77 \cdot 0$ & $93 \cdot I$ \\
\hline
\end{tabular}

The unweighted mean composition of the faeces for each calf, computed from the separate determinations, is summarized in Table 9, and Table ro summarizes the statistical significance of the changes in percentage composition.

Table 9. Mean percentage composition of faecal dry matter of the calves

\begin{tabular}{|c|c|c|c|c|c|c|}
\hline & \multicolumn{2}{|c|}{ Calf no. $\mathbf{r}$} & \multicolumn{2}{|c|}{ Calf no. 2} & \multicolumn{2}{|c|}{ Calf no. 3} \\
\hline Constituent & $\begin{array}{l}\text { Pre- } \\
\text { liminary } \\
\text { period, } \\
\text { diet no. } 6\end{array}$ & $\begin{array}{l}\text { N-free } \\
\text { period, } \\
\text { diet no. } 7\end{array}$ & $\begin{array}{l}\text { Pre- } \\
\text { liminary } \\
\text { period, } \\
\text { diet no. } 6\end{array}$ & $\begin{array}{l}\text { N-free } \\
\text { period, } \\
\text { diet no. } 7\end{array}$ & $\begin{array}{l}\text { Pre- } \\
\text { liminary } \\
\text { period, } \\
\text { diet no. } 6\end{array}$ & $\begin{array}{l}\text { N-free } \\
\text { period, } \\
\text { diet no. } 7\end{array}$ \\
\hline Dry matter in fresh faeces & $17 \cdot 6$ & $\mathrm{II} 4$ & $20 \cdot 1$ & 20.6 & 19.5 & $6 \cdot 8$ \\
\hline Ash in dry matter & $2 I \cdot 4$ & $8 \cdot 0$ & $14 \cdot 1$ & $7 \cdot 2$ & $12 \cdot 9$ & $8 \cdot 9$ \\
\hline Total fat in dry matter & $35 \cdot 3$ & $64 \cdot 1$ & $28 \cdot 0$ & $66 \cdot 0$ & $39 \cdot 5$ & $63 \cdot 7$ \\
\hline $\mathrm{N} \times 6.25$ in dry matter & $37 \cdot 1$ & $12 \cdot 6$ & $58 \cdot 4$ & 10.2 & $47^{\circ} \cdot 2$ & $12 \cdot 7$ \\
\hline $\begin{array}{l}\text { Residual material, i.e. 'carbo- } \\
\text { hydrate' }\end{array}$ & $6 \cdot 2$ & $15^{\cdot 2}$ & -0.5 & $10 \cdot 2$ & 0.3 & $16 \cdot 7$ \\
\hline $\begin{array}{l}\text { Fat present as soaps } \dagger \\
\text { Fat present as neutral fat }+ \text { free } \\
\text { fatty acids }+ \text { unsaponifiable residue }\end{array}$ & $\begin{array}{l}54 \cdot 6 \\
45 \cdot 4\end{array}$ & $\begin{array}{l}38 \cdot 6 \\
6 I \cdot 4\end{array}$ & $\begin{array}{l}63 \cdot 1 \\
36 \cdot 9\end{array}$ & $\begin{array}{l}\text { I } 5 \cdot 3 \\
84 \cdot 7\end{array}$ & $\begin{array}{l}37 \cdot 3 \\
62 \cdot 7\end{array}$ & $\begin{array}{l}23 \cdot 1 \\
76 \cdot 9\end{array}$ \\
\hline $\mathrm{N}$ present as non-protein $\mathrm{N} f$ & $24^{\circ} 2$ & $<4$ & $21 \cdot 0$ & $12 \cdot 1$ & 22.4 & $14 \cdot 7$ \\
\hline
\end{tabular}

- 'This animal had access to sawdust bedding for 2 days before the preliminary period began. Some was eaten and small quantities appeared in the faeces during the first 4 days of the preliminary period. The value does not represent undigested dietary carbohydrate.

$\dagger$ Percentage of total fat. 
Table 10. Mean composition of the faeces of the calves and digestibility of the diet given in the preliminary period and in the nitrogen-free feeding period

\begin{tabular}{|c|c|c|c|c|}
\hline & $\begin{array}{c}\text { Preliminary } \\
\text { period, } \\
\text { diet no. } 6\end{array}$ & $\begin{array}{c}\text { N-free } \\
\text { period, } \\
\text { diet no. } 7\end{array}$ & Difference & Significance \\
\hline Ash in dry faeces $(\%)$ & $16 \cdot 1$ & $8 \cdot 0$ & $8 \cdot 1 \pm 2 \cdot 76$ & N.S. \\
\hline Fat in dry faeces $(\%)$ & $34 \cdot 3$ & $64 \cdot 6$ & $30.3 \pm 4.04$ & $P<0.02$ \\
\hline $\mathbf{N}$ in dry faeces $(\%)$ & $7 \cdot 6$ & $I \cdot 9$ & $5.7 \pm 1 \cdot 10$ & $P<0.05$ \\
\hline Residual 'carbohydrate' (\%) & $2 \cdot 0$ & $15 \cdot 5$ & $13 \cdot 5 \pm 2 \cdot 38$ & $P<0.01$ \\
\hline Fat excreted (g.) & $10 \cdot 5$ & $74^{\circ} 9$ & $64.4 \pm 1 \cdot 75$ & $P<0.01$ \\
\hline $\begin{array}{l}\text { Apparent digestibility of } \\
\text { dietary fat }(\%)\end{array}$ & $91 \cdot 7$ & $44^{\circ} 9$ & $46 \cdot 8 \pm 3 \cdot 56$ & $P<0.01$ \\
\hline $\begin{array}{l}\text { Energy excreted in faeces } \\
\text { (Cal./day) }\end{array}$ & 172 & 844 & $672 \pm 36 \cdot 9$ & $P<0.01$ \\
\hline $\begin{array}{l}\text { 'Apparent digestibility' of } \\
\text { dietary energy }(\%)\end{array}$ & $92 \cdot 9$ & $66 \cdot 5$ & $26 \cdot 4 \pm 2 \cdot 52$ & $P<0.01$ \\
\hline
\end{tabular}

It will be noted that large and statistically significant mean changes occurred in the fat content and the $\mathrm{N}$ content of the faeces when the $\mathrm{N}$-free diet was given and that the increase in the residual fraction (presumably carbohydrate) was highly significant. In so far as the dry-matter excretion increased during the $\mathrm{N}$-free feeding period, it is clear that there were marked changes in the total daily excretion of fat and in the digestibility of fat. These are shown in the lower part of Table Io.

Total fat excretion increased six times during the experimental period, and the digestibility of dietary fat dropped to less than half the normal value. In this respect, the digestibility data recorded by Schneider (1947), based on a study of the older German and Russian literature, suggest that the apparent digestibility for the calf of butterfat in cow's milk is $93-99$, values only slightly higher than those we have found with our diets, containing dried skim milk with lard as a source of fat. The increase in dry-matter excretion, shown in Table 8 , is thus largely due to a decrease in fat absorption, since $75 \%$ of the increased faecal dry-matter excretion consisted of fat. This failure to digest fat is also shown by the lowered content of soaps in the faeces of the calves (see Table 9) and obviously implies a considerable reduction in the number of calories available to the animal. The faecal calories and the 'digestibility' of the ingested calories were calculated from the compositional data, using factors of $9^{\cdot I} \mathrm{Cal} . \mathrm{g}$. for fat, $4^{.0}$ for carbohydrate and $5^{.6}$ for protein $(\mathrm{N} \times 6.25)$. These results are also shown in Table ro and emphasize the importance of this fall in digestibility of fat when maintenance of an adequate calorie intake is being considered.

The reason for such a fall in digestibility of fat on feeding diet no. 7 is not certain. The fat level remained fairly constant and the same fat was used throughout the experiment. This suggests, but does not prove, that a factor, or factors, in dried skim milk is essential for fat absorption. Whether this is the phosphoprotein of the dried skim milk or the small quantity of phospholipin present or yet another factor remains to be determined.

Nitrogen balance, metabolic faecal nitrogen and endogenous urinary nitrogen. The $\mathrm{N}$-balance results are shown in Table I I. Statistical analysis of these results showed 
that there was no significant change in faecal $\mathrm{N}$ excretion but a highly significant $(P<0.01)$ change in urinary $\mathrm{N}$ excretion and $\mathrm{N}$ balance when the $\mathrm{N}$-free diet was given.

Table I1. Nitrogen-balance results for the calves (g./day)

\begin{tabular}{|c|c|c|c|c|c|c|c|c|c|c|c|c|}
\hline \multirow{3}{*}{$\begin{array}{l}\text { Calf } \\
\text { no. }\end{array}$} & \multicolumn{4}{|c|}{ Preliminary period, diet no. 6} & \multicolumn{4}{|c|}{$\begin{array}{l}\text { Experimental period, } \\
\text { N-free diet no. } 7\end{array}$} & \multicolumn{4}{|c|}{ Final period, diet no. 6} \\
\hline & & Excre & etion & & & Excr & etion & & & Excr & retion & \\
\hline & Intake & Faeces & Urine & Balance & Intake & Faeces & Urine & Balance & Intake & Faeces & Urine & Balance \\
\hline $\begin{array}{l}\mathbf{I} \\
\mathbf{2}\end{array}$ & $\begin{array}{l}15 \cdot 86 \\
12 \cdot 34\end{array}$ & $\begin{array}{l}1 \cdot 25 \\
2 \cdot 02\end{array}$ & $\begin{array}{l}7 \cdot 87 \\
6 \cdot 69\end{array}$ & $\begin{array}{l}+6 \cdot 74 \\
+3 \cdot 62\end{array}$ & $\begin{array}{l}0.04 \\
0.04\end{array}$ & $\begin{array}{l}2 \cdot 45 \\
1 \cdot 76\end{array}$ & $\begin{array}{l}2 \cdot 99 \\
2 \cdot 24\end{array}$ & & & $\begin{array}{l}2 \cdot 49 \\
I \cdot 15\end{array}$ & $\begin{array}{l}9 \cdot 42 \\
5 \cdot 90\end{array}$ & \\
\hline 3 & $15 \cdot 31$ & $2 \cdot 17$ & 9.42 & $+3 \cdot 72$ & 0.04 & $2 \cdot 08$ & $2 \cdot 52$ & $-4 \cdot 56$ & $14 \cdot 29$ & $1 \cdot 49$ & $7 \cdot 93$ & $+4 \cdot 87$ \\
\hline Mean & 14.50 & 1.81 & $7 \cdot 99$ & +470 & 0.04 & $2 \cdot 10$ & $2 \cdot 5^{8}$ & $-4 \cdot 64$ & 13.73 & $1 \cdot 71$ & $7 \cdot 75$ & +4.27 \\
\hline
\end{tabular}

The faecal $\mathrm{N}$ excreted when a $\mathrm{N}$-free diet is given represents the so-called metabolic $\mathrm{N}$ of the faeces, that is the inevitable drain of $\mathrm{N}$ from the tissues incidental to food ingestion and digestion. This has been shown in the rat to be proportional to the dry matter ingested (Schneider, 1934, 1935). In adult ruminants the metabolic faecal $\mathrm{N}$ is approximately $0.5 \mathrm{~g} . / 100 \mathrm{~g}$. dry matter consumed (Blaxter \& Mitchell, 1948) a value about five times as great as that observed in the rat or man. Since large quantities of fibre in the diet of rats increase the metabolic faecal N (Mitchell, 1926) this difference between ruminants and non-ruminants has been regarded as entirely due to the higher fibre content of the ruminant's diet. In these milk-fed calves, much lower values of metabolic $\mathrm{N}$ would, therefore, be expected than in mature ruminants. When, however, the $\mathrm{N}$ excretion in the $\mathrm{N}$-free period is related to the dry-matter intake of these calves, values of $0.45,0.42$ and $0.41 \mathrm{~g} . / 100 \mathrm{~g}$. dry matter ingested are obtained, values well within the range of those quoted by workers with adult ruminants. These results might suggest that the species differences in metabolic faecal $\mathrm{N}$ excretion quoted above are true species differences established at a very early age. A more probable explanation, however, is that the digestibility of the dry matter of the diet determines the metabolic faecal $\mathrm{N}$ excretion. This contention is supported by the fact that the $\mathbf{N}$ excretion of the calves was, on the average, higher during the $\mathrm{N}$-free period than in the periods of normal feeding when digestibility of the total diet was high. The solubility and distribution of the $\mathbf{N}$ of the faeces produced on normal diets differed from that found when $\mathrm{N}$-free diets were given. Mukherjee (1946), working with Indian bullocks, has similarly shown that the metabolic faecal $\mathbf{N}$ excretion is more closely related to drymatter excretion than to dry-matter intake. Such an explanation would account for the high values found in these calves fed on diets free of fibre.

The urinary $\mathrm{N}$ in the $\mathrm{N}$-free period represents the endogenous urinary $\mathrm{N}$ of the calf. The results are shown graphically in Fig. I. It will be noted that the continuing metabolism of $N$ (Thomas, 1909) in the calf is very small, constant levels of urinary $N$ being reached within 2 days. The urinary $\mathrm{N}$ was much lower during the $\mathrm{N}$-free period than the urinary $\mathrm{N}$ excreted during the period in which diet no. 6 was fed. The interpretation of this observation will be discussed later.

The magnitude of the $\mathrm{N}$ balances during the period of $\mathrm{N}$ inanition was approximately 
related to the body size of the calves. During the period of diarrhoea in calf no. 3 , the loss of $\mathrm{N}$ from the body was $13.5 \mathrm{~g}$./day despite the fact that food intake was only reduced to $67 \%$ of the normal over the period concerned. This figure, representing katabolism of body $\mathrm{N}$, suggests that an adequate supply of energy was being ingested by the calves during the $\mathrm{N}$-free period despite the low digestibility of their ration.

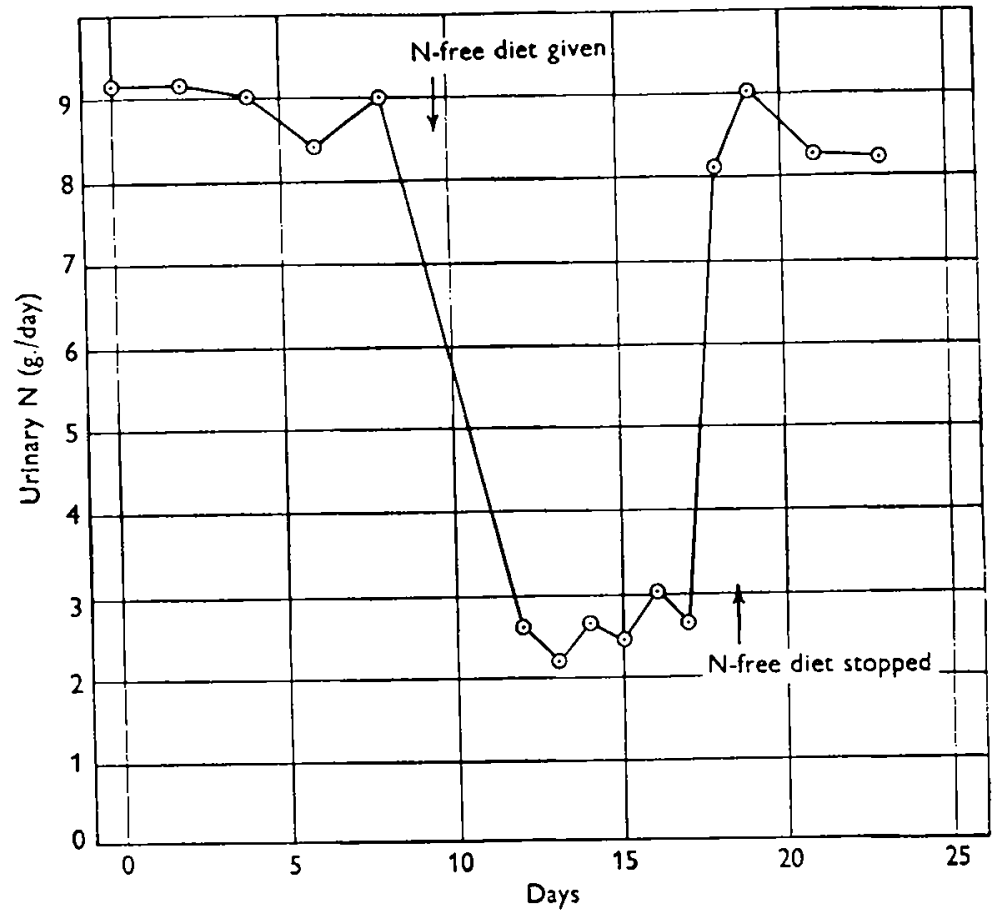

Fig. 1. Effect of a nitrogen-free diet on the urinary nitrogen of the calf.

Distribution of urinary nitrogen. The distribution of urinary $\mathrm{N}$ for each calf is summarized in Table 12. It will be noted that the data relating to allantoin $N$ are not

Table 12. Mean daily excretion of nitrogen in different nitrogenous metabolites in the urine of the calves

\begin{tabular}{|c|c|c|c|c|c|c|c|c|c|c|c|c|c|}
\hline \multirow[b]{2}{*}{ Metabolite } & \multicolumn{4}{|c|}{$\begin{array}{c}\text { Preliminary period, } \\
\text { diet no. } 6\end{array}$} & \multicolumn{4}{|c|}{$\begin{array}{c}\text { Experimental period, } \\
N \text {-free diet no. } 7\end{array}$} & \multicolumn{4}{|c|}{$\begin{array}{l}\text { Final period, } \\
\text { diet no. } 6\end{array}$} & \multirow{2}{*}{$\begin{array}{l}\text { Statistical } \\
\text { significance } \\
\text { of change } \\
\text { during N-free } \\
\text { period }\end{array}$} \\
\hline & $\begin{array}{l}\text { Calf } \\
\text { no. I }\end{array}$ & $\begin{array}{c}\text { Calf } \\
\text { no. } 2\end{array}$ & $\begin{array}{c}\text { Calf } \\
\text { no. } 3\end{array}$ & Mcan & $\begin{array}{l}\text { Calf } \\
\text { no. I }\end{array}$ & $\begin{array}{r}\text { Calf } \\
\text { no. } 2\end{array}$ & $\begin{array}{r}\text { Calf } \\
\text { no. } 3\end{array}$ & Mean & $\begin{array}{l}\text { Calf } \\
\text { no. I }\end{array}$ & $\begin{array}{l}\text { Calf } \\
\text { no. } 2\end{array}$ & $\begin{array}{l}\text { Calf } \\
\text { no. } 3\end{array}$ & Mean & \\
\hline $\begin{array}{l}\text { Urea (g.) } \\
\text { Ammonia (g.) } \\
\text { Total urea and } \\
\text { ammonia (g.) }\end{array}$ & $\begin{array}{l}4 \cdot 55 \\
0.98 \\
5 \cdot 54\end{array}$ & $\begin{array}{l}4.20 \\
0.68 \\
4.88\end{array}$ & $\begin{array}{l}5 \cdot 35 \\
1 \cdot 82 \\
7 \cdot 17\end{array}$ & $\begin{array}{l}4 \cdot 70 \\
I \cdot 16 \\
5 \cdot 87\end{array}$ & $\begin{array}{l}I \cdot 04 \\
0.34 \\
I \cdot 39\end{array}$ & $\begin{array}{l}I \cdot 02 \\
0.2 I \\
I \cdot 22\end{array}$ & $\begin{array}{l}1 \cdot 07 \\
0.46 \\
1 \cdot 53\end{array}$ & $\begin{array}{l}1 \cdot 04 \\
0.34 \\
1 \cdot 38\end{array}$ & $\begin{array}{l}6 \cdot 38 \\
1 \cdot 12 \\
7 \cdot 50\end{array}$ & $\begin{array}{l}3 \cdot 66 \\
0 \cdot 76 \\
4 \cdot 41\end{array}$ & $\begin{array}{l}4.95 \\
0.65 \\
5.60\end{array}$ & $\begin{array}{l}5 \cdot 00 \\
0 \cdot 84 \\
5 \cdot 84\end{array}$ & \\
\hline $\begin{array}{l}\text { Creatine (g.) } \\
\text { Creatinine (g.) } \\
\text { Uric acid (g.) } \\
\text { Allantoin (g.) }\end{array}$ & $\begin{array}{l}0.248 \\
0.346 \\
0.050 \\
0.811\end{array}$ & $\begin{array}{l}0.221 \\
0.342 \\
0.029 \\
0.575\end{array}$ & $\begin{array}{l}0.189 \\
0.454 \\
0.054 \\
0.746\end{array}$ & $\begin{array}{l}0.219 \\
0.380 \\
0.045 \\
0.711\end{array}$ & $\begin{array}{l}0.22 I \\
0.22 I \\
0.048\end{array}$ & $\begin{array}{r}0.025 \\
0.344 \\
0.028 \\
\text { See tex }\end{array}$ & $\begin{array}{l}0.063 \\
0.392 \\
0.047 \\
\text {, this p }\end{array}$ & $\begin{array}{l}0.103 \\
0.319 \\
0.041 \\
\text { age. }\end{array}$ & $\begin{array}{l}0.139 \\
0.354 \\
0.069\end{array}$ & $\begin{array}{r}0.112 \\
0.257 \\
0.026 \\
\text { See tex }\end{array}$ & $\begin{array}{l}0.173 \\
0.384 \\
0.086 \\
\text {, this p }\end{array}$ & $\begin{array}{l}0.144 \\
0.332 \\
0.060 \\
\text { age. }\end{array}$ & $\begin{array}{c}P<0.05 \\
\text { N.S. } \\
\text { N.S. }\end{array}$ \\
\hline
\end{tabular}

complete. The method of Larson $\left(193^{1-2}\right)$ was used to determine allantoin during the preliminary period, and when this method was applied to the urines excreted during the $\mathrm{N}$-free period it gave values greatly in excess of expectation, necessitating con- 
siderable dilution of the urine. The apparent increase was so great that the residual $\mathrm{N}$ became negative. Interference was traced to the relatively large quantities of reducing sugar excreted by the calves, which were not removed by the procedure of phosphotungstic-acid precipitation employed. The method was therefore abandoned. Later, stored samples representative of the $\mathrm{N}$-free period were analysed by a slight modification of Young \& Conway's (1942) method using the Rimini-Schryver reaction. Results were obtained which agreed with those obtained in the preliminary period using Larson's method. The urinary excretion of sugar during the low-N period was probably an alimentary glycosuria comparable to the lactosuria noted in calves by Rojas, Schweigert \& Rupel (1948). The urinary concentration of sugar estimated by Benedict's (I9II) method rose to over $2 \%$.

Urine volume declined during the low- $\mathrm{N}$ period and the specific gravity of the urine rose. This probably was a result of adaptation to the high loss of water in the faeces. Consequently the concentration of some of the metabolites in urine increased during the low- $\mathrm{N}$ period. The last column of Table 12 shows the statistical significance of the mean changes in $\mathrm{N}$ distribution in the period when the $\mathrm{N}$-free diet was given. The fall in total $\mathrm{N}$ excretion was largely due to a fall in the excretion of urea and ammonia, with a smaller fall in creatine elimination. Creatinine excretion was not changed significantly nor was the excretion of uric acid. Although the data are not complete, the few analyses for allantoin did not indicate any fall in its excretion during the period of $\mathrm{N}$-free feeding. Table 13 expresses the percentage distribution of the urinary metabolites. Uric acid, creatinine and residual $\mathrm{N}$ (largely allantoin) make up a far greater proportion of the total $\mathrm{N}$ during the $\mathrm{N}$-free period than during protein feeding. The interpretation of this table is given in the summary.

Table 13. Distribution of nitrogen in different nitrogenous metabolites in the urine of the calves, expressed as percentages of total urinary nitrogen

$\begin{array}{lccc}\text { Metabolite } & \begin{array}{c}\text { Preliminary } \\ \text { period, } \\ \text { diet no. }\end{array} & \begin{array}{c}\text { Experimental } \\ \text { period, } \\ \text { diet no. }\end{array} & \begin{array}{c}\text { Final } \\ \text { period, } \\ \text { diet no.6 }\end{array} \\ \text { Urea } & 58.8 & 37.8 & 64.4 \\ \text { Ammonia } & 14.5 & 12.1 & 10.8 \\ \text { Urea and ammonia } & 73.4 & 49.9 & 75.2 \\ \text { Creatinine } & 4.7 & 11.8 & 4.3 \\ \text { Creatine } & 2.7 & 3.9 & 1.9 \\ \text { Uric acid } & 0.6 & 1.5 & 0.7 \\ \text { Residual N } & 18.6 & 32.9 & 17.9\end{array}$

- According to analyses by the method of Young \& Conway (1942), over $50 \%$ of this consists of allantoin.

Basal metabolism. The results of duplicate determinations are given in Table ${ }_{4} 4$. The agreement between duplicate determinations was close and analysis of variance of heat production showed that the coefficient of variation was less than $4 \%$ (three degrees of freedom). The metabolism of the calves was intense since, if Brody's (1945) estimates of the basal metabolism of the adult cow are correct, then their metabolism per $\mathrm{kg}$. body-weight was three times that found at maturity. 
Table I4. Respiratory metabolism of the calves

\begin{tabular}{|c|c|c|c|c|c|c|}
\hline \multirow[b]{2}{*}{ Variable measured } & \multicolumn{2}{|c|}{$\begin{array}{c}\text { Calf no. I } \\
\text { Determination no. }\end{array}$} & \multicolumn{2}{|c|}{$\begin{array}{c}\text { Calf no. } 2 \\
\text { Determination no. }\end{array}$} & \multicolumn{2}{|c|}{$\begin{array}{c}\text { Calf no. } 3 \\
\text { Determination no }\end{array}$} \\
\hline & $\mathbf{I}$ & 2 & I & 2 & I & 2 \\
\hline Environmental temperature $\left({ }^{\circ} \mathrm{F}.\right)$ & 73 & 72 & 68 & 68 & 64 & $6 \mathrm{I}$ \\
\hline Pulse rate/min. & 59 & 55 & 57 & 56 & 52 & 53 \\
\hline Respiratory rate/min. & $16 \cdot 8$ & 15.5 & $16 \cdot 0$ & $14 \cdot 8$ & $19 \cdot 4$ & $18 \cdot 5$ \\
\hline Minute volume of respiration (1.) & $4 \cdot 52$ & 479 & 3.88 & $2 \cdot 98$ & 3.98 & $4 \cdot 23$ \\
\hline Tidal air (ml.) & 269 & 309 & 243 & 201 & 205 & 229 \\
\hline Oxygen consumed (1./hr.) & $13 \cdot 17$ & $12 \cdot 69$ & 10.70 & 10.27 & 13.06 & $12 \cdot 96$ \\
\hline Carbon dioxide produced $(1 . / \mathrm{hr}$.) & $9 \cdot 80$ & $9 \cdot 43$ & $7 \cdot 95$ & $7 \cdot 21$ & $9 \cdot 67$ & $9 \cdot 13$ \\
\hline & 0.74 & 0.74 & 0.74 & 0.71 & 0.74 & $0.7 x$ \\
\hline Heat production (Cal./24 hr.) & 1495 & I $440^{\circ}$ & 1214 & 1155 & 1481 & 1457 \\
\hline Heat production (Cal./kg./24 hr.) & $42 \cdot 7$ & $4 \mathrm{I} \cdot \mathbf{2}$ & $43 \cdot I$ & $4 r \cdot 0$ & $45 \cdot 9$ & $45 \cdot \mathrm{I}$ \\
\hline
\end{tabular}

The metabolic faecal $\mathrm{N}$ excretion of the calves and the digestibility of the diets have already been adequately considered in the appropriate sections. This discussion deals only with the relation of endogenous $\mathrm{N}$ metabolism to basal metabolism. It is necessary in the first instance to assess the validity of the determinations of endogenous $\mathrm{N}$ and basal metabolism that have been presented. Too high an estimate of either quantity would result in many difficulties of interpretation of the ratio of the one to the other.

The prerequisites for a basal metabolism determination were probably maintained, the possible exception being that the critical temperature of the calf may be somewhat higher than the environmental temperature at which the determinations were made. This might be inferred from the results with calf no. 3 given in Table 14. This calf's metabolism was higher than that of the others and the environmental temperature was lower than had been maintained for calves nos. I and 2. Muscular repose was maintained, and the long periods of observation employed obviated errors due to any initial disturbance of the animals.

The endogenous $\mathrm{N}$ excretion was determined when the calves were ingesting a diet of low digestibility and when a further part of the dietary energy was lost as sugar in the urine. This low intake of energy probably accounted for the fall in the pulse rates of the calves after an initial rise when the diet had been given for a few days. Calculations of the metabolizable calories available to the animal from analytical data for urine and faeces gave in all instances values above the directly determined basal energy metabolism, and, provided that the heat increment of the diet was small-a reasonable assumption in an animal not converting a large portion of its dietary carbohydrate to lower fatty acids-these intakes of metabolizable energy should have been adequate to meet basal requirements. A further point is that in two calves creatine completely disappeared from the urine by the end of the period and in the other it reached a very low level. It would appear, therefore, that these nitrogen excretions were truly endogenous.

The endogenous $\mathrm{N}$ metabolism of the calves and their basal metabolism are shown in 'Table I5. For comparative purposes the two equations for basal metabolism and endogenous $\mathrm{N}$ metabolism estimation from body-weight for mature animals of different 
Table 15. Relation between the basal metabolism of the calves and their endogenous nitrogen metabolism

\begin{tabular}{|c|c|c|c|c|c|c|}
\hline \multirow{2}{*}{$\begin{array}{l}\text { Calf } \\
\text { no. }\end{array}$} & \multirow{2}{*}{$\begin{array}{l}\text { Weight } \\
\text { (kg.) }\end{array}$} & \multicolumn{2}{|c|}{ Endogenous $\mathrm{N}$ metabolism } & \multicolumn{2}{|c|}{ Basal metabolism } & \multirow{2}{*}{$\begin{array}{c}\text { Ratio } \\
\text { mg. } \mathbf{N} \text { :Cal. }\end{array}$} \\
\hline & & (g./day) & (mg./kg./day) & (Cal./day) & (Cal./kg./day) & \\
\hline $\begin{array}{l}1 \\
2 \\
3\end{array}$ & $\begin{array}{l}35 \cdot 7 \\
27 \cdot 8 \\
31 \cdot 0\end{array}$ & $\begin{array}{l}2 \cdot 99 \\
2 \cdot 24 \\
2 \cdot 52\end{array}$ & $\begin{array}{l}83 \cdot 8 \\
80 \cdot 8 \\
8 \mathrm{r} \cdot 0\end{array}$ & $\begin{array}{l}1467 \\
1185 \\
1469\end{array}$ & $\begin{array}{l}41 \cdot 9 \\
42 \cdot 0 \\
45 \cdot 5\end{array}$ & $\begin{array}{l}2 \cdot 00 \\
1 \cdot 93 \\
1 \cdot 78\end{array}$ \\
\hline Mean & $31 \cdot 5$ & 一 & $8 I \cdot 9$ & - & $43 \cdot 1$ & $1 \cdot 90 \pm 0.07$ \\
\hline $\begin{array}{l}\text { Expected } \\
\text { values in } \\
\text { mature ani- } \\
\text { mals (Brody, } \\
\text { 1945) }\end{array}$ & $\begin{array}{r}31.5 \\
8 \cdot 0\end{array}$ & - & $\begin{array}{l}55^{\cdot 6} \\
79 \cdot 3\end{array}$ & $\overline{-}$ & $\begin{array}{l}28 \cdot 1 \\
43 \cdot x\end{array}$ & - \\
\hline
\end{tabular}

species (Brody, I945) have been used to calculate, firstly, the expected basal metabolism and endogenous $\mathrm{N}$ metabolism of a mature animal of the same mean body-weight as the calves and, secondly, the expected endogenous metabolism of a mature animal having the same basal metabolism per $\mathrm{kg}$. body-weight (a much smaller animal of course) as the experimental calves. The results in Table 15 suggest that the endogenous $\mathrm{N}$ metabolism of the young calf is far more intense per kg. body-weight than that of a mature animal either of the same size or the same species (cf. Table $\mathrm{r}$ ). The same is true of the basal energy metabolism. The ratio of endogenous nitrogen to basal metabolism, the so-called Terroine-Sorg-Matter law, appears the same in the young calf as in mature animals of different species, namely about $2.0 \mathrm{mg}$. $\mathrm{N} /$ basal Cal. of heat production.

The percentage distribution of the nitrogenous metabolites in the urine of the calves on the $\mathrm{N}$-free diet presented in Table ${ }_{13}$ shows that some $\mathrm{II}_{1} .8 \%$ of the endogenous $\mathrm{N}$ can be accounted for by the irreversible reaction creatine $\rightarrow$ creatinine. A further $25 \%$ or more is clearly the result of enzymic degradation of purine compounds of the body. Of the total, however, $50 \%$ is due to an inevitable katabolism resulting in the end-products urea and ammonia. Whether this katabolism represents the destruction of tissue proteins to supply amino-acids, methyl groups, or other carbon fragments essential to the economy of the animal is not known. The percentage of creatinine $\mathrm{N}$ in the endogenous $\mathrm{N}$ excretion of these calves was lower than the percentage normally found in adult man. Brody (1945) has shown that in mature animals the percentage of the total endogenous $\mathrm{N}$ present as creatinine increases with body size, for creatinine excretion is related more to body mass than to body surface. The percentage to be expected in a mature animal with the same body-weight as the calves is 15.8 . The ratio expected in a mature animal with the same basal metabolism, however, is I I. 9 , a value in very close agreement with the value of $x \times 8$ found in these studies.

\section{SUMMARY}

I. Experiments with three young dairy calves are described in which the endogenous nitrogen and basal metabolism were determined.

2. The sole diet of the calves was a semi-synthetic liquid diet resembling milk. When protein was an ingredient of the diet, body-weight gains were slightly subnormal. 
3. The apparent digestibility of the dry matter dropped from 94.0 to $77.0 \%$ on giving a $\mathrm{N}$-free diet. This was associated with a decrease from $9 \mathrm{I} \cdot 7$ to $44.9 \%$ in the apparent digestibility of the dietary fat, and a decrease in the 'digestibility' of the calories of the diet from $92^{\cdot} \cdot 9$ to $66.5 \%$. The percentage of the total fat present as soaps fell when the $\mathrm{N}$-free diet was given.

4. Nitrogen balances were +4.70 and $+4.27 \mathrm{~g}$./day in the periods in which a diet containing dried-milk protein was given. Negative balances of $-4.64 \mathrm{~g}$./day occurred when the $\mathrm{N}$-free diet was given.

5. The $\mathrm{N}$ content of the faeces during the $\mathrm{N}$-free feeding period was $0.427 \pm$ $0.013 \mathrm{~g} . / 100 \mathrm{~g}$. dry matter ingested. 'This result is discussed in relation to species differences in metabolic faecal $\mathrm{N}$ excretion, and it is suggested that the quantity of dry faeces excreted per day rather than dry-matter intake determines metabolic $\mathbf{N}$ excretion.

6. The endogenous urinary $\mathrm{N}$ was $8 \mathrm{r} \cdot 9 \mathrm{mg}$. $/ \mathrm{day} / \mathrm{kg}$. body-weight. The basal energy metabolism was $43^{\cdot} \cdot \mathrm{C}$ Cal. $/ \mathrm{kg}$./day. The amount of endogenous $\mathrm{N}$ excreted per Cal. of basal heat produced was $1 \cdot 90 \pm 0.068$. This value for these animals with their intense metabolism in relation to their body size is in close agreement with that found by Smuts (1935) for mature animals of different species.

7. The distribution of the urinary $\mathrm{N}$ changed on giving the $\mathrm{N}$-free diet. Creatine excretion fell to a very low level; creatinine, uric acid and allantoin excretion remained constant, while urca and ammonia excretion increased.

8. 'I'he distribution of the urinary $\mathrm{N}$ when the $\mathrm{N}$-free diet was given suggests that $12 \%$ of the endogenous metabolism involves the irreversible reaction creatine $\rightarrow$ creatinine, $25 \%$ or more involves purine katabolism, and $50 \%$ involves reactions terminating in the excretion of urea and ammonia.

\section{REFERENCES}

Aschaffenburg, R., Bartlett, S., Kon, S. K., Walker, D. M., Briggs, C., Cotchin, E. \& Lovell, R. (r949). Brit. F. Nutrit. 3, 196 .

Bate, W., Dwight, E. \& Cannon, C. Y. (1946). F. Dairy Sci. 29, 4I.

Benedict, S. R. (1911). F. Amer. med. Ass. 57, 1193.

Benedict, S. R. \& Franke, E. (1922). F. biol. Chem. 52, 387 .

Blaxter, K. L. \& Howells, A. (195 r). Brit. F. Nutrit. 5, 25.

Blaxter, K. L. \& Mitchell, H. H. (1948). F. Anim. Sci. 7, 35 I.

Bricker, M., Mitchell, H. H. \& Kinsman, G. M. (1945). F. Nutrit. 30, 269.

Brody, S. (1930). Res. Bull. Mo. agric. Exp. Sta. no. 143.

Brody, S. (1945). Bioenergetics and Growth. New York: Reinhold Publishing Corporation.

Burroughs, E. W., Burroughs, H. S. \& Mitchell, H. H. (1940). F. Nutrit. 19, 271.

Buschmann, A. (1907). Landw. VersSta. I01, I.

Ferguson, W. S. \& Neave, O. (1943). Y. agric. Sci. 33, 95.

Folin, O. (1905). Amer. F. Physiol. 13, 117.

Folin, O. (1914). \%. biol. Chem. 17, 469.

Hart, E. B., Humphrey, G. C. \& Morrison, F. B. (1912). F. biol. Chem. 13, 133.

Honcamp, F., Koudela, S. \& Muller, E. (1923). Biochem. Z. 143, I I I.

Hutchinson, J. C. D. \& Morris, S. (1936). Biochem. F. 30, 1682.

Kehar, N. D., Mukherjee, R. \& Sen, K. C. (1943). Indian Y. vet. Sci. 13, 257.

Larson, H. W. ( $1931-2)$. F. biol. Chem. 94, 727.

Macrae, T. F., El Sadr, M. M. \& Sellers, K. C. (1942). Biochem. F. 36, 460.

Miller, J. I. (1937). F. agric. Res. 55, 467.

Mitchell, H. H. (1926). Bull. nat. Res. Coun., Wash., no. 55.

Mitchell, H. H. (1929). Bull. nat. Res. Coun., Wash., no. 67.

Mitchell, H. H. (1948). In Proteins and Amino Acids in Nutrition, p. 46. [M. Sahyun, editor]. New York: Reinhold Publishing Corporation. 
Mukherjee, R. (1946). Studies of protein metabolism in relation to cattle nutrition. Thesis, University of Dacca.

Murlin, J. R., Edwards, L. E., Hawley, E. E. \& Clark, L. C. (1946). F. Nutrit. 31, 533.

Palmer, W. W., Means, J. H. \& Gamble, J. I. (1914). F. biol. Chem. 19, 239.

Rojas, J., Schweigert, B. S. \& Rupel, I. W. (1948). Э. Dairy Sci. 31, 81.

Saxon, G. J. (1914). F. biol. Chem. 1, 131 .

Schneider, B. H. (1934). Biochem. F. 28, 360 .

Schneider, B. H. (1935). F. biol. Chem. 109, 249.

Schneider, B. H. (1947). Feeds of the World, their Digestibility and Composition. University of West Virginia Agricultural Experiment Station.

Schoenheimer, R. \& Rittenberg, D. (1940). Physiol. Rev. 20, 218.

Smuts, D. B. (1935). F. Nutrit. 9, 403.

Steenbock, H., Nelson, V. E. \& Hart, E. B. (1915). Res. Bull. Wis. agric. Exp. Sta. no. 36.

Swanson, E. W. \& Herman, H. A. (1943). Res. Bull. Mo. agric. Exp. Sta. no. 372.

'Terroine, E. F. \& Sorg-Matter, H. (1927). Arch. int. Physiol. 29, 121.

Thomas, K. (1909). Arch. Anat. Physiol., Lpz., Physiol. Abt. p. 219.

Treichler, R. (1939). The relationship between basal metabolism and endogenous nitrogen metabolism. Thesis, Lniversity of Illinois.

Van Slyke, D. D. \& Cullen, G. E. (1910). F. biol. Chem. 24, 117.

Wiese, A. C., Johnson, B. C., Mitchell, H. H. \& Nevens, W. B. (1947). F. Dairy Sci. 30, 87.

Young, E. G. \& Conway, C. F. (1942). F. biol. Chem. 142, 839 .

\title{
The Nutrition of the Young Ayrshire Calf
}

\section{A Spirometer for the Determination of the Respiratory Exchange of the Calf}

\author{
By K. L. BLAXTER (in Receipt of a Senior Award of the \\ Agriclitural Research Council) \\ AND A. HOWELLS \\ Hannah Dairy Research Institute, Kirkhill, Ayr
}

(Received $17 \mathscr{F u l l}_{1950)}$

Determination of the energy exchange of farm animals by methods involving the principle of indirect calorimetry presents a number of technical difficulties. These are mostly due to the higher rate of lung ventilation in farm animals than in man. In cattle and sheep the minute volume of the respiration increases with increasing environmental temperature since in these species loss of water vapour from the respiratory passages is an extremely important channel of heat emission. With young cattle of the same weight as man, low environmental temperatures are associated with minute volumes of approximately 8-10 1., values quite comparable to those recorded for man, but at environmental temperatures approaching the animal's body temperature, values of over $25 \mathrm{l}$. may be obtained. Methods of indirect calorimetry involving the use of the Douglas bag or of the Tissot spirometer have never been popular in studies of energy metabolism in farm animals (Orr \& Magee, 1923) since the large volumes of expired air soon fill the apparatus, and most of the work in this field has been conducted with large respiration chambers through which a measured stream of air is passed. Such instruments are expensive and cumbersome in use. Brody (I945), however, has 